\title{
Ny screening gir sikrere diagnose
}

Bruk av screeninginstrumentet 4AT kan forbedre diagnostiseringen av akutt delirium.

\section{Geir Vegar Berg}

Forskningsveileder og førsteamanuensis

Sykehuset Innlandet, Lillehammer og Norges teknisk-vitenskapelige universitet, Gjøvik

\section{Leiv Otto Watne}

Lege og postdoc.

Oslo universitetssykehus og Universitetet i Oslo

\section{Edith Roth Gjevjon}

Førsteamanuensis

Høyskolen Diakonova

\section{\begin{tabular}{|l|l|l|l|l}
\hline Delirium & Forvirring & Kognitiv svikt & Undersøkelse \\
\hline
\end{tabular}}

\section{Hovedbudskap}

Delirium (akutt forvirring) er en vanlig og alvorlig tilstand, men blir ofte oversett. 4AT er et screeningverkt $\varnothing y$ som er i $\varnothing$ kende bruk i flere land, og vi har nå oversatt dette til norsk. En gruppe forskere planlegger å gjøre validering av verktøyet både i sykehus og i kommunehelsetjenesten. 
Et instrument for rask screening av akutt forvirring eller delirium og kognitiv svikt kan forbedre diagnostikken gjennom sikrere identifikasjon av symptomer.

Sykepleierens tilstedeværelse i pasientforløpet er av stor betydning, når uklare og varierende symptomer gjør det vanskelig å avdekke den alvorlige tilstanden (1) delirium er. Rapid assement test for Delirium (4AT) er et screeninginstrument for å identifisere symptomer på delirium og kognitiv svikt og er i utstrakt bruk internasjonalt (2).

\section{Delirium}

Delirium kjennetegnes ved akutt endring i bevissthetsnivå, oppmerksomhet og kognisjon. Man ser også ofte persepsjonsforstyrrelser og endret søvn- eller våkenhetsrytme. Akutt forvirring har ofte et svingende forløp og skal ikke kunne forklares av en allerede kjent kognitiv sjukdom, som for eksempel demens. Tilstanden er vanlig ved akutt somatisk sykdom $(3,4)$. Dette gjelder særlig hos eldre pasienter, og vi ser det ofte hos pasienter med hoftebrudd (4).

\section{Stressende}

Delirium kan være veldig stressende for pasienten som for eksempel har mange skremmende hallusinasjoner, og er en belastning også for pårørende. I tillegg er tilstanden forbundet med dårlig prognose, varig funksjonsnedsettelse og institusjonalisering (5). Delirium er underdiagnostisert, og man kan anta at behandlingskostnadene for relativt «enkle» akutte tilstander, som hoftebrudd, $\varnothing$ ker.

\section{Ikke avdekket}

Ofte blir ikke delirium avdekket og diagnostisert. Dette skyldes subjektiv diagnostikk uten bruk av relevante screeninginstrumenter, ved bruk av klinisk skjønn alene, samt legers og sykepleieres tiltro til egen individuelle erfaring. Det er særlig den hypoaktive varianten av delirium med nedsatt psykomotorisk tempo, initiativløshet og somnolens som er vanskelig å avdekke, da dette ofte blir forvekslet med depresjon eller demens.

\section{Lett å bruke}

Systematisk screening og tidlig identifikasjon av symptomer kan redusere tilfellene av delirium (6). Internasjonalt er CAM (Confusion Assessment Method) det mest brukte diagnostiske instrumentet for delirium (7). Det har kommet flere instrumenter for diagnostikk og vurdering av pasienter med delirium de siste årene. Vi fant at 4AT var verdt å oversette, evaluere og teste i klinisk praksis fordi instrumentet er kortfattet og lett å bruke. Screeningen kan gjennomføres på mindre enn to minutter og kan gjennomføres av ulike grupper helsepersonell i en travel hverdag. 


\section{Beskrivelse}

4AT er en test for rask vurdering av akutt forvirring og kognitiv svikt. Instrumentet er utviklet av en gruppe skotske leger i Edinburgh Delirium Research Group (8) og er validert $(2,9)$. Instrumentet består av fire vurderingsområder som skåres fra o-2 eller 0-4 poeng: 1) Pasientens årvåkenhet, 2) mental vurdering, 3) pasientens oppmerksomhet og 4) akutt endring eller fluktuasjon i pasientens tilstand. Instrumentet gir en rask førstegangsvurdering av delirium eller kognitiv svikt, men er i seg selv ikke et diagnostisk verkt $\varnothing \mathrm{y}$. 4AT fungerer som en beslutningsst $\varnothing t t e$ for sykepleier ved at de kommuniserer symptomene som avdekkes til lege dersom de antyder delirium eller kognitiv svikt. Legen avgjør om videre diagnostisering skal igangsettes. 4AT kan brukes av sykepleiere eller annet helsepersonell ved kontakt med pasienten eller når man mistenker akutt forvirring.

\section{Oversatt}

4AT er nå oversatt til norsk og vil i første omgang bli testet og validert og deretter tatt i bruk i klinisk praksis og forskning. En tverrfaglig gruppe med to sykepleiere, to leger og en fysioterapeut oversatte instrumentet uavhengig av hverandre. De fem forslagene ble deretter sendt ut til en utvidet gruppe, som i tillegg besto av fire leger, for vurdering og revidering. Den omforente versjonen av instrumentet ble så sendt til en tospråklig person som oversatte vår norske $4 \mathrm{AT}$ tilbake til engelsk. Deretter ble den engelske oversettelsen sendt inn til professor MacLullich som leder gruppen som er ansvarlig for den originale engelske versjonen. MacLullich hadde noen små kommentarer på vår oversettelse som vi i siste runde har justert $\mathrm{i}$ vår norske oversettelse av 4AT.

Endelig versjon er tilgjengelig på Norsk geriatrisk forenings nettsider: http://legeforeningen.no/Fagmed/Norsk-geriatrisk-forening/Geriatrisk-test--ogundervisningsmateriell/tester-og-registreringsskjemaer/4-AT/ 


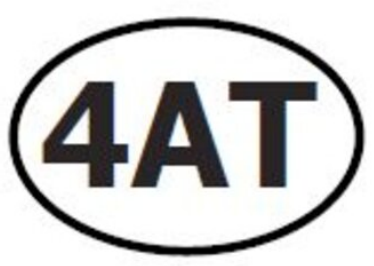

Screening for delirium og kognitiv svikt
Pasientens navn:

Pasientnummer

Dato:

Tidspunkt:

Testen er utført av:

[1] ÁRVÁKENHET (forholder seg normalt til omgivelsene)

Pasienten virker tydelig døsig (dvs. vanskelig á vekke og/ eller er ápenbart søvnig ved undersøkelsen) eller motorisk urolig/hyperaktiv. Observer pasienten. Hvis pasienten sover, forsøk á vekke pasienten med vanlig stemme eller ved varsom beroring pá skulderen. Be pasienten oppgi navn og adresse til hjelp med vurderingen.

$\begin{array}{ll}\text { Normal (helt árvåken, ikke urolig ved undersøkelse) } & 0 \\ \text { Lett søvnig }<10 \text { sekunder etter oppvákning, deretter normal } & 0 \\ \text { Tydelig unormal(t) } & \mathbf{4}\end{array}$

[2] AMT4 (Forkortet mental vurdering)

Alder, fodselsdato, sted (navnet pá sykehuset eller bygning), àrstall

$\begin{array}{ll}\text { Ingen feil } & 0 \\ 1 \text { feil } & 1 \\ 2 \text { feil eller flerefikke testbar } & 2\end{array}$

\section{[3] OPPMERKSOMHEI}

Spør pasienten: "Kan du i baklengs rekkefølge nevne for meg árets máneder, begynn med desembers

A hjelpe pasienten med et innledende spørsmál «hva er máneden før december? y er tillatt

Rekkefølgen av árets máneder baklengs

$\begin{array}{ll}\text { Oppgir } 7 \text { máneder eller flere korrekt } & 0 \\ \text { Begynner, men klarer <7 máneder/ avslár ả begynne } & 1 \\ \text { lkke testbar (er uvel, døsig, uoppmerksom) } & 2\end{array}$

[4] AKUTT ENDRING ELLER FLUKTUASJON I TILSTAND

Holdepunkter for betydelige endininger eller fluktuasjoner knyttet til: árvákenhet, kognisjon,

annen mental funksjon

(F.eks. paranoide symptomer, hallusinasjoner) oppstät i lopet av de siste to uker og fremdeles tilstede de siste 24 timer

Nei

Ja

24: mulig delirium og eller kognitiv svikt

1-3: mulig kognitiv svikt

0: delirium eller alvorlig kognitiv svikt usannsynlig (men

fremdeles mulig delirium hvis informasjon under punkt [4]

er ufullstendig)

\section{VEILEDNING}

Versjon 1.2. Informasjon og nedlasting www the 4AT com

Instrumentet 4AT er utformet for en rask forstegangsvurdering av delirium og kogntiv svikt. En skár pa 4 eller mer antyder delirium, men er ikke diagnostisk. En mer detalert vurdering av mental status kan være aktuelt for en setter diagnosen. En skả pả 1-3 antyder kognitiv svikt. Mer detaljert kognitiv testing og informasjon om pasienten er pákrevd. En skár pá 0 ekskluderer ikke sikkert delirium eller kognitiv svikt. Mer detaliert testing kan vøre pákrevd, avhengig av den kliniske situasjonen. Vurderinger under punkt 1-3 er kun basert pá svikt. Mer detaljert testing kan være pákrevd, avhengig av den kliniske situasjonen. Vurderinger under punkt 1-3 er kun basert pá
observasjon av pasienten nár undersokelsen giores. Punkt 4 krever informasjon fra én eller flere kilder, som din egen kunnskap om observasjon av pasienten nár undersokelsen gjores. Punkt 4 krever informasjon fra én eller flere kilder, som din egen kunnskap om kommunikasjonsutfordringer (horselsnedsettelse, dysfasi, mangel pá sprák) nár vurderingen giennomfores og resultatene tolkes.

Ârvákenhet: Endret nivå av årvåkenhet er sannsynligvis delirium i en generell sykehus-setting. Hvis pasienten viser betydelig endret árvảkenhet ved undersokelsen, sett skár 4 pá dette punktet.

AMT4 (Forkortet mental vurdering - 4): Denne skáren kan overfores fra AMT10 hvis denne er giort rett for 4AT. Akutt endring eller AMT4 (Forkortet mental vurdering - 4): Denne skáren kan overiores fra AMT10 hvis denne er gjort rett for 4AT. Akutt endring eller
fluktuerende tilstand: Fluktuerende tilstand kan oppstá uten delirium i noen tiffeller hos personer med demens, men tydelig fluktuerende tilstand indikerer delinum. For á avdekke hallusinasjoner og/ eller paranoide tanker, spor pasienten sporsmál som: "Er du bekymret for

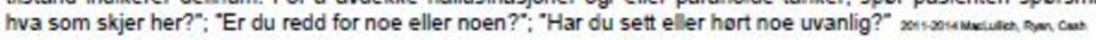

Norsk versjon: Skjema ved screening for delirium og kogntiv svikt. 


\section{Referanser:}

1. Kirkevold M. Kartlegging. I: Kirkevold M, Brodtkorb K, -Ranhoff AH. (2O14). Geriatrisk sykepleie: god omsorg til den gamle pasienten. Oslo, Gyldendal akademisk:122-145.

2. Bellelli G, Morandi A, Davis DH, Mazzola P, Turco R, Gentile S, Ryan T, Cash H, Guerini F, Torpilliesi T, Del Santo F, Trabucchi M, Annoni G, Maclullich AM. Validation of the 4AT, a new instrument for rapid delirium screening: a study in 234 hospitalised older people. Age Ageing 2014;14:496-502.

3. American Psychiatric Association. Diagnostic and statistical manual of mental disorders. 5. utg. Arlington, VA: American Psychiatric Association, 2013. 4. Neerland BE, Watne LO, Wyller TB. Delirium hos eldre pasienter. Tidsskr Nor Legeforen 2013; 133: 1596 - 600 .

5. Krogseth, M, Wyller TB, Engedal K, Julieb $\varnothing$ V. Delirium is a risk factor for institutionalization and functional decline in older hip fracture patients. Journal of psychosomatic research 2014; 76(1): 68-74.

6. Björkelund KB, Hommel A, Thorngren KG, Gustafson L, Larsson S, Lundberg D. Reducing delirium in elderly patients with hip fracture: a multi-factorial intervention study. Acta Anaesthesiologica Scandinavica 2010; 54(6): 678-688. 7. Wei LA, Fearing MA, Sternberg EJ, Inouye SK. The Confusion Assessment Method: a systematic review of current usage. Journal of the American Geriatrics Society $2008 ; 56(5) ; 823-830$.

8. 4AT - Rapid assement test for Delirium. URL: http://www.the4at.com. [ 28.11.15]

9. Lees R, Corbet S, Johnston C, Moffitt E, Shaw G, Quinn TJ. Test accuracy of short screening tests for diagnosis of delirium or cognitive impairment in an acute stroke unit setting. Stroke 2013; Nov;44(11):3078-83. 